\title{
Generation of Quaternary adakites due to two-stage differentiation of arc magma beneath central Myanmar
}

\author{
TAKASHI SANO ${ }^{1}$, KENICHIRO TANI ${ }^{1}$, SHIGEKAZU \\ YONEDA $^{2}$, HLA MIN ${ }^{3}$, THAUNG HTIKE ${ }^{4}$, ZIN MAUNG \\ MAUNG THEIN $^{5}$, OSAMU ISHIZUKA ${ }^{6}$, NAO \\ KUSUHASHI $^{7}$, REIKO KONO ${ }^{8}$, MASANARU TAKAI ${ }^{9}$ AND \\ CHRIS CONWAY ${ }^{6}$ \\ ${ }^{1}$ National Museum of Nature and Science \\ ${ }^{2}$ National Museum of Nature and Science, Tokyo \\ ${ }^{3}$ Meiktila University \\ ${ }^{4}$ University of Yangon \\ ${ }^{5}$ University of Mandalay \\ ${ }^{6}$ Geological Survey of Japan \\ ${ }^{7}$ Ehime University \\ ${ }^{8}$ Keio University \\ ${ }^{9}$ Kyoto University \\ Presenting Author: sano@kahaku.go.jp
}

Popa volcano, which is the largest edifice of three Quaternary volcanoes (Popa, Monywa and Singu) in central Myanmar, consists of a lower basaltic plateau (Popa Plateau) and upper stratovolcano. Building on detailed geological surveys, our new ${ }^{40} \mathrm{Ar}-{ }^{39} \mathrm{Ar}$ and $\mathrm{K}-\mathrm{Ar}$ age determinations show that the age of Popa Plateau, which is associated with a volcanic plug (Taunkalat), is 0.8-0.6 Ma and construction of the stratovolcano began about 0.4 Ma. Moreover, the K-Ar age of air fall scoria layers in sedimentary basin deposits (Irrawaddy Formation) beneath Popa Plateau indicates that volcanic activity at Popa began at least 3 Ma.

Our petrological description, along with major, trace element and $\mathrm{Sr}-\mathrm{Nd}$ isotopic data for 30 rocks show that Popa Plateau is composed of alkaline basalts and the stratovolcano consists of alternating layers of alkaline basalts and adakites (high $\mathrm{Mg}^{\#}$ andesite).

Popa adakites are the dominant volcanic rocks of the stratovolcano and are present as lava flows and crater rim agglomerates with typical adakite mineralogy (e.g., hornblende phenocryst with accessory minerals of apatite and zircon) and geochemistry (e.g., high $\mathrm{Sr} / \mathrm{Y}$ with low HREE concentrations). The adakitic magmas cannot be derived from Popa alkaline basaltic magma, but they share many trace element signatures and $\mathrm{Sr}-\mathrm{Nd}$ isotope ratios with picritic basalts from Monywa volcano. Mineralogical and geochemical evaluations imply that the most primitive adakitic melt can be produced from the picritic basalt magma by fractional crystallization of a garnetbearing assemblage at high pressure ( 1 GPa; Moho depth). Further investigations show that the chemical trend from the most primitive adakite to evolved ones $\left(\mathrm{SiO}_{2} \sim 60 \mathrm{wt} \%\right)$ can be explained by assimilation-fractional crystallization at pressure, temperature, and water content conditions of $\sim 500 \mathrm{MPa}$ (depth near the base of upper crust), $\sim 900{ }^{\circ} \mathrm{C}$, and $\sim 5 \mathrm{wt} \%$. Therefore, we need not introduce the widely accepted generation model of adakitic magma, partial melting of subducted crust, to explain the 